J. Product. \& Dev., 23(1): 39-59 (2018)

\title{
REPLACING NITROGEN FERTILIZATION BY USING ORGANIC AND BIOFERTILIZERS ON COSTATA PERSIMMON TREES.
}

\author{
H. A. Ennab ${ }^{1}$; M.A. M. Soliman ${ }^{2}$ and G. B. Mikhael $^{2}$ \\ 1- Citrus Research Department. \\ 2- Deciduous Fruit Trees Research Department. \\ Horticulture Research Institute, Agriculture Research Center, Giza, Egypt
}

\section{ABSTRACT}

The present study was conducted during 2015, 2016 and 2017 seasons to study the effect of replacing mineral nitrogen fertilization by organic nitrogen and biofertilizers on Costata persimmon trees, under calcareous soil conditions. The treatments consist of $T_{1}(100 \%$ mineral nitrogen $), T_{2}(75 \%$ mineral nitrogen $+25 \%$ organic nitrogen), $T_{3}$ (50\% mineral nitrogen $+25 \%$ organic nitrogen + biofertilizer), T4 (25\% mineral nitrogen $+50 \%$ organic nitrogen + biofertilizer) and $T_{5}(100 \%$ organic nitrogen). Rice straw compost was used as a source of organic nitrogen and $N_{2}$-fixing free living bacteria namely Azotobacter chroococcum and Azospirillum lipoferum as a source of biofertilizers. The obtained results can be summarized as follows: Treatment of 50\% mineral nitrogen $+25 \%$ organic nitrogen with biofertilizers gave the highest values of vegetative growth in terms of shoot number/branch, shoot length, leaf numbers per shoot and leaf area of Costata persimmon trees compared to mineral nitrogen fertilizers only. Moreover, treatments included organic and biofertilizers were raising leaf content values of chlorophyll, $N, P, K$, $\mathrm{Ca}, \mathrm{Fe}, \mathrm{Mn}$ and $\mathrm{Zn}$ especially in the second season. As for yield, treatment of $50 \%$ mineral nitrogen $+25 \%$ organic nitrogen + biofertilizer and $75 \%$ mineral nitrogen $+25 \%$ organic nitrogen produced the highest yield in terms of number of fruits/tree, weight ( $\mathrm{kg} / \mathrm{tree})$ and total yield (ton/feddan). All treatments led to improving properties of fruit quality especially treatment of $50 \%$ mineral nitrogen $+25 \%$ organic nitrogen +biofertilizers. Also, treatments containing organic and biofertilizer led to reducing nitrate and nitrite values in fruit juice comparing with $100 \%$ mineral nitrogen fertilizer.

Conclusively, this treatment is recommended: $150 \%$ mineral nitrogen $+25 \%$ organic nitrogen + biofertilizers). This treatment gave 
the best growth, yield, fruit quality and nutritional status of Costata persimmon trees.

Key words: Diospyros kaki, compost, biofertilizers, nutritional status, quality, nitrate, nitrite.

\section{INTRODUCTION}

Japanese persimmon (Diospyros kaki, L.) is one of the most promising deciduous fruit species in Egypt, due to its low chilling requirements, adapts to the warm climate and increasing demands of local consumption. So, persimmon increased rapidly and cultivation spreads in many area in Egypt. Such extension in cultivated area encourages establishing more studies to finding out a good alternative to reduce uses of chemical fertilizers to maintain clean environment, free from pollution and to produce healthy fruits, free from chemicals and safe on human health (Ennab, 2016). Nitrogen fertilization is one of the most important elements for growth, reproductive behavior and ensure economic yield with a good quality of Costata persimmon trees (Choi et al., 2013). Meanwhile, mineral nitrogen fertilizers causes the accumulation of harmful residual substances like $\mathrm{NO}_{3}$ and $\mathrm{NO}_{2}$ which have deleterious effects on soil, water and atmosphere pollution, and reflected on animal and human health. Also, it had adversely affected the soil fertility, water quality, yield and quality of the products (Mohammadi and Ziarati, 2016). In order to improve productivity and access to safe fruits for local consumer and high exportation potential as well as reduce the costs, the farmers should be tend to minimizing intensive amounts of chemical fertilizers especially mineral nitrogen fertilization through satisfying the nitrogen requirement from organic nitrogen and biofertilization (Suhag, 2016). Using organic nitrogen such compost or fresh organic manure and biofertilizers have numerous benefits such as a valuable source of many nutrients like macro and microelements, increasing soil organic matter, improves soil structure and increases the water-holding capacity in sandy soils and improves drainage in clay soils, on other words, organic manures and biofertilizers has a great importance for sustainable production and to improve the soil physical, chemical and biological properties (Zayan et al., 2016). Moreover, compost and biofertilizers are a good alternative to reduce uses of mineral nitrogen fertilizers on different fruit crops (Abou Grah, 2004; Abd El Migeed et al., 2007; Mansour and Shaaban, 2007 and Salama et al., 2012). In this respect, several studies were accomplished for producing organic fruits through Clean Agriculture which avoiding partially the application of chemicals fertilizers and encouraging the application of organic 
and biofertilizers (Masoud, 2012; Ahmed et al., 2013 \& 2015 and Mikhael and Aziz, 2016 a \& b).

Therefore, this investigation was conducted to study the effect of replacing mineral nitrogen fertilization by organic nitrogen and biofertilizers added on Costata persimmon trees under calcareous soil conditions.

\section{MATERIALS AND METHODS}

The present study was carried out during 2015, 2016 and 2017 seasons in a private orchard at Abu El-Matamir, El-Bohaira governorate, Egypt, on eight years old Costata persimmon (Diospyros kaki, L.) trees budded on Tarabuls (Diospyrous lotus) rootstock, planted at $4 \times 4$ meter apart in calcareous soil under flood irrigation system. The first year was considered as a preliminary trail, and data was recorded in 2016 \& 2017 seasons. The results of soil and rice straw compost analysis according to Page et al., (1982) are given in Table 1. Forty five trees uniform in growth, vigour and productivity were selected, and subjected to the same cultural practices commonly adopted on the orchard, except those dealing with application of organic and inorganic nitrogen as well as biofertilizers. Trees were arranged in a randomized complete block design, each treatment replicated three time with three tree per replicate.

Five treatments were chosen to study the effect of replacing mineral nitrogen fertilization by organic nitrogen and biofertilizers compared with $100 \%$ mineral nitrogen as follows:

$\mathbf{T}_{\mathbf{1}}: 100 \%$ recommended doses of mineral nitrogen as $300 \mathrm{~g} \mathrm{~N} /$ tree/year via ammonium nitrate $33.5 \% \mathrm{~N}$ at rate of $900 \mathrm{~g} /$ tree/year.

$\mathbf{T}_{2}: 75 \%$ mineral nitrogen from recommended doses via ammonium nitrate $33.5 \% \mathrm{~N}$ at rate of $675 \mathrm{~g} /$ tree/year $+25 \%$ organic nitrogen via rice straw compost $1.58 \% \mathrm{~N}$ at rate of $4.75 \mathrm{~kg} /$ tree/year.

$\mathbf{T}_{3}$ : $50 \%$ mineral nitrogen from recommended doses via ammonium nitrate $33.5 \% \mathrm{~N}$ at rate of $450 \mathrm{~g} /$ tree/year $+25 \%$ organic nitrogen via rice straw compost $1.58 \% \mathrm{~N}$ at rate of $4.75 \mathrm{~kg} /$ tree/year, $+25 \mathrm{~g} /$ tree/year biofertilizers.

$\mathbf{T}_{\mathbf{4}}$ : $25 \%$ mineral nitrogen from recommended doses via ammonium nitrate $33.5 \% \mathrm{~N}$ at rate of $225 \mathrm{~g} /$ tree/year $+50 \%$ organic nitrogen via rice straw compost $1.58 \% \mathrm{~N}$ at rate of $9.5 \mathrm{~kg} /$ tree $/$ year, $+25 \mathrm{~g} /$ tree/year biofertilizers.

$\mathbf{T}_{5}: 100 \%$ organic nitrogen via rice straw compost $1.58 \% \mathrm{~N}$ at rate of 19 $\mathrm{kg} /$ tree/year. 
Table (1): Analysis of rice straw compost and physical, chemical of the experimental soil.

\begin{tabular}{|c|c|c|c|c|}
\hline \multirow{3}{*}{ parameters } & \multicolumn{2}{|c|}{ Soil analysis } & \multicolumn{2}{|c|}{ Rice straw compost } \\
\hline & \multicolumn{2}{|c|}{ Soil depth cm } & \multirow{2}{*}{ Parameters } & \multirow{2}{*}{ Value } \\
\hline & $\mathbf{0}-\mathbf{3 0}$ & $30-60$ & & \\
\hline Sand \% & 76.28 & 77.88 & weight of dry $\mathrm{kg} / \mathrm{m}^{3}$ & 583.5 \\
\hline Silt \% & 15.26 & 15.12 & Moisture \% & 23.8 \\
\hline Clay \% & 8.46 & 7.00 & Organic matter $\%$ & 38.21 \\
\hline Texture & Sandy & Sandy & Organic carbon $\%$ & 22.18 \\
\hline $\mathrm{pH} 1: 2.5$ & 8.10 & 8.20 & pH $1: 10$ & 7.30 \\
\hline $\mathrm{EC} \mathrm{dSm}^{-1} 1: 5$ & 0.44 & 0.33 & $\mathrm{EC} \mathrm{dSm}^{-1} 1: 5$ & 1.35 \\
\hline Organic mater $\%$ & 1.15 & 0.89 & $\mathrm{C} / \mathrm{N}$ ratio & 14.04 \\
\hline $\mathrm{K}^{+} \mathrm{meq} / \mathrm{l}$ & 0.57 & 0.49 & $\mathrm{~N} \%$ & 1.58 \\
\hline $\mathrm{Ca}^{++}$meq/1 & 3.13 & 2.82 & $\mathrm{P} \%$ & 2.32 \\
\hline $\mathrm{Mg}^{++} \mathrm{meq} / \mathrm{l}$ & 2.29 & 1.64 & $\mathrm{~K} \%$ & 2.58 \\
\hline $\mathrm{Na}^{+}$meq/l & 2.96 & 2.33 & $\mathrm{Ca} \%$ & 1.78 \\
\hline $\mathrm{HCO}_{3}{ }^{-} \mathrm{meq} / \mathrm{l}$ & 1.06 & 0.81 & $\mathrm{Mg} \%$ & 0.93 \\
\hline $\mathrm{Cl}^{-}$meq/l & 4.27 & 3.94 & Fe ppm & 633 \\
\hline $\mathrm{SO}_{4}^{--} \mathrm{meq} / 1$ & 3.62 & 2.53 & Mn ppm & 99 \\
\hline $\mathrm{CaCO}_{3}$ & 15.7 & 16.3 & $\mathrm{Zn} \mathrm{ppm}$ & 38 \\
\hline $\mathrm{CO}_{3}^{--}$ & 0.00 & 0.00 & $\mathrm{Cu} \mathrm{ppm}$ & 26 \\
\hline
\end{tabular}

Amount of mineral nitrogen as ammonium nitrate $(33.5 \% \mathrm{~N})$ was divided in to three doses and added as, $50 \%$ at late February, $25 \%$ at the end of June and $25 \%$ at the end of July. Also, $625 \mathrm{~g} /$ tree/year potassium sulphate $48 \% \mathrm{~K}_{2} \mathrm{O}$ was applied on two doses, at mid April and mid June. Whereas, $1.12 \mathrm{~kg} /$ tree/year super phosphate $15.5 \% \quad \mathrm{P}_{2} \mathrm{O}_{5}$ was added once in early February. Potassium sulphate and super phosphate were applied to all treatments as a source of $\mathrm{K}$ and $\mathrm{P}$ in both seasons. Rice straw compost $1.58 \% \mathrm{~N}$ as a source of organic nitrogen was broadcasted and incorporated into the root zone of tree in winter service at late December in both seasons. A mixture of $\mathrm{N}_{2}$-fixing free living bacteria namely Azotobacter chroococcum and Azospirillum lipoferum (5 x $10^{7} \mathrm{cfu} / \mathrm{g}$ peat moss) as biofertilizers was added in the first week of March in both seasons. Rice straw compost and bacteria were obtained from Soil Microbiology Department, Sakha Agric. Res. Station, Kafr El-Sheikh governorate, Egypt.

Four branches on each tree were selected and tagged in four directions for measuring and determination the following data:

\section{Vegetative growth:}

In the first week of August, shoots formed in branch were counted, and 12 shoots on each replicate were sampled from tagged branches to measuring shoot length $(\mathrm{cm})$ and leaves number per shoot was recorded, 
also twenty mature leaves were sampled from shoots to determining leaf area $\left(\mathrm{cm}^{2}\right)$ using a leaf area meter Model Li 3100 area- meter.

\section{Nutritional status:}

Samples of Twenty mature leaves taken to determined leaf area, five leaves taken from this samples to determine chlorophyll $\mathrm{a}, \mathrm{b}$ and its total by using N, N dimethyl formamide according to Moran and Porath (1980). The remaining leaf samples were dried at $70^{\circ} \mathrm{C}$ to a constant weight, then ground and digested according to Jackson (1967) by using the mixture of concentrated Sulfuric acid $\left(\mathrm{H}_{2} \mathrm{SO}_{4}\right)+$ per chloric $\left(\mathrm{HClO}_{4}\right)$ (5: 1) to determine the elements $\mathrm{N}, \mathrm{P}, \mathrm{K}, \mathrm{Ca}, \mathrm{Mg}, \mathrm{Fe}, \mathrm{Mn}$ and $\mathrm{Zn}$. Total nitrogen \% was determined by using the micro-kjeldahl method as described by Pregl (1945), Phosphorus \% was determined coloremetrically as described by Murphy and Riley (1962), Potassium \% was estimated by using flame photometer as described by Brown and Lillelland (1974), Ca, Mg, Fe, Mn and $\mathrm{Zn}$ were assayed with Atomic Absorption spectrophotometer (Unican SP 1900) according to Chapman and Pratt (1961).

\section{Final fruit set and final fruit drop percentages:}

Number of flowers, fruitlets at initial set (i.e. 15 days after full bloom) and fruit at harvest time were counted on the selected main branches for calculated final fruit set and fruit drop percentages by the following equations:

Final fruit set $\%=\frac{\text { No.of harvested fruits }}{\text { No. of flowers }} \times 100$

Final fruit drop \%

\section{Yield:}

$$
=\frac{\text { No.of fruitlets at initial set }- \text { No. of harvested fruits }}{\times 100 \quad \text { No.of fruitlets at initial set }}
$$

Yield was harvested at September $7^{\text {th }}$ and $29^{\text {th }}$ in 2016 and 2017, respectively. Yield of each replicate was determined as number and weight $(\mathrm{kg})$ of fruits/tree, and total yield as ton/feddan.

\section{Fruit quality:}

Ten fruit samples were taken at random from each replicate to determine fruit quality as follow: fruit weight $(\mathrm{g})$, fruit length and diameter $(\mathrm{cm})$, and fruit firmness $\left(\mathrm{lb} / \mathrm{inch}^{2}\right)$ was measured at two opposite sides on the equator of each fruit using pressure tester at $5 / 16$ plunger. Total soluble solids (TSS\%) was determined by hand refractometer, total acidity as malic acid, total tannin content in fruit juice, nitrate $\left(\mathrm{NO}_{3}\right)$ and nitrite $\left(\mathrm{NO}_{2}\right)$ 
content $(\mathrm{mg} / 100 \mathrm{ml}$ juice) in fruit juice were determine according to (A.O.A.C., 1990).

Statistical analysis was done as analysis of variance according to Snedecor and Cochran (1990), and the least significant differences (L.S.D. at $5 \%$ level) was used to compare the main values.

\section{RESULTS AND DISCUSSION}

\section{Vegetative growth:}

Results presented in Table (2) showed that, mineral nitrogen, organic nitrogen and biofertilizers had positive effect on vegetative growth parameters in terms of shoot number/branch, shoot length leaves number per shoot and leaf area of Costata persimmon trees in both seasons. Fertilizing Costata persimmon trees with $\mathrm{T}_{1}\left(100 \%\right.$ mineral nitrogen) and $\mathrm{T}_{3}(50 \%$ mineral nitrogen $+25 \%$ organic nitrogen + biofertilizer) tended to gave the highest values of vegetative growth parameters without significant differences between them in both seasons. On contrary, using $100 \%$ rice straw compost as a source of nitrogen only produced the lowest significant values of vegetative growth parameters as compared to other treatments in both seasons. Whereas that, $\mathrm{T}_{2}(75 \%$ mineral nitrogen $+25 \%$ organic nitrogen) and $\mathrm{T}_{4}(25 \%$ mineral nitrogen $+50 \%$ organic nitrogen + biofertilizer) gave intermediate values of most vegetative growth parameters without significant differences between them in both seasons. These results are in harmony with those obtained by Shah et al., (2006); Abd El Wahab, (2011) and Ahmed et al., (2015). They concluded that, soil application of $50 \%$ organic nitrogen $+50 \%$ mineral nitrogen gave the highest significant values of vegetative growth i.e., shoot length leaves number per shoot, leaf area and leaf dry weight on different fruit species. In this respect, Mikhael and Aziz (2016a) who revealed that Anna apple trees fertilized with 50\% organic manure $+50 \%$ mineral fertilizer gave the highest significant values of vegetative growth in terms of shoot length, shoot diameter, leaf area and leaf dry weight.

Generally, it is obvious from data in Table (2) that, tree vigour and vegetative growth of Costata persimmon trees were significantly improved by using combination among mineral nitrogen, organic nitrogen and biofertilizers especially treatment of $50 \%$ mineral nitrogen $+25 \%$ organic nitrogen + biofertilizer. This increment in vegetative growth as a result of treatments may be due to stimulating availability of nutrients, organic matter and reducing soil $\mathrm{pH}$ as well as natural hormones present in the combination 
of mineral and organic nitrogen fertilizers with biofertilizers. This might also be attributed to the improved nitrogen use efficiency and consequently improved nitrogen uptake by trees resulting into faster cell division and cell elongation; and consequently increased the tree growth and size. These observations were corroborated with the findings of El Salhy et al., (2010) and Mansour et al., (2013). In this respect, Gabr and Nour El-Din (2012) concluded that nitrogen-fixing bacteria Azospirillum lipoferum enhancing the nitrogen and produce natural hormones like gibberellins and cytokines that are responsible for plant growth promotion that occurs upon inoculation onto plants.

Table (2). Effect of replacing mineral nitrogen by organic nitrogen and biofertilizers on some growth parameters of Costata persimmon trees.

\begin{tabular}{|l|c|c|c|c|c|c|c|c|}
\hline \multirow{2}{*}{ Treatments } & \multicolumn{2}{|c|}{$\begin{array}{c}\text { Shoot number per } \\
\text { branch }\end{array}$} & \multicolumn{2}{c|}{$\begin{array}{c}\text { Shoot length } \\
(\mathrm{cm})\end{array}$} & \multicolumn{2}{c|}{$\begin{array}{c}\text { Leaves number } \\
\text { per shoot }\end{array}$} & \multicolumn{2}{c|}{$\begin{array}{c}\text { Leaf area } \\
\left(\mathrm{cm}^{2}\right)\end{array}$} \\
\cline { 2 - 9 } & 2016 & 2017 & 2016 & 2017 & 2016 & 2017 & 2016 & 2017 \\
\hline $\mathbf{T}_{\mathbf{1}}$ & 17.28 & 18.55 & 72.42 & 74.18 & 21.47 & 22.37 & 32.28 & 34.00 \\
$\mathbf{T}_{\mathbf{2}}$ & 15.67 & 16.45 & 68.88 & 70.20 & 20.25 & 20.90 & 28.90 & 29.55 \\
$\mathbf{T}_{\mathbf{3}}$ & 16.44 & 17.32 & 70.98 & 73.33 & 20.60 & 21.37 & 31.77 & 32.88 \\
$\mathbf{T}_{\mathbf{4}}$ & 15.33 & 16.11 & 68.65 & 69.77 & 20.15 & 20.77 & 27.52 & 28.19 \\
$\mathbf{T}_{\mathbf{5}}$ & 13.77 & 14.23 & 63.86 & 65.28 & 18.76 & 19.41 & 26.38 & 26.83 \\
\hline LSD at 5\% & $\mathbf{1 . 1 0}$ & $\mathbf{1 . 3 9}$ & $\mathbf{1 . 5 8}$ & $\mathbf{1 . 9 4}$ & $\mathbf{0 . 9 0}$ & $\mathbf{0 . 7 8}$ & $\mathbf{1 . 0 8}$ & $\mathbf{1 . 5 3}$ \\
\hline
\end{tabular}

$\mathrm{T}_{1}: 100 \%$ Mineral nitrogen; $\mathrm{T}_{2}: 75 \%$ Mineral nitrogen $+25 \%$ Organic nitrogen; $\mathrm{T}_{3}: 50 \%$ Mineral nitrogen $+25 \%$ Organic nitrogen + Biofertilizer; $\mathrm{T}_{4}: 25 \%$ Mineral nitrogen $+50 \%$ Organic nitrogen + Biofertilizer and $\mathrm{T}_{5}: 100 \%$ Organic nitrogen.

\section{Nutritional status:}

\section{Leaf chlorophyll content $\left(\mu \mathrm{g} / \mathrm{cm}^{2}\right)$ :}

Regarding the effect of mineral and organic nitrogen and biofertilizers on leaf chlorophyll content of Costata persimmon trees, results in Table (3) clearly showed that, chlorophyll a, b and its total content were significantly improved with nitrogen fertilization treatments in both seasons. Costata persimmon trees fertilized with $\mathrm{T}_{5}\left(100 \%\right.$ organic nitrogen) and $\mathrm{T}_{3}(50 \%$ mineral nitrogen $+25 \%$ organic nitrogen + biofertilizer) recorded the highest values of chlorophyll $\mathrm{a}, \mathrm{b}$ and its total content in both seasons, respectively. On the other hand, $\mathrm{T}_{1}\left(100 \%\right.$ mineral nitrogen) and $\mathrm{T}_{2}(75 \%$ mineral nitrogen $+25 \%$ organic nitrogen) recorded the least values of leaf chlorophyll content in both seasons. Whereas, $\mathrm{T}_{4}(25 \%$ mineral nitrogen + $50 \%$ organic nitrogen + biofertilizer) gave intermediate values in this respect. These results are similar to those of previous studies (Ahmed et al., 2013 and El Gioushy and Baiea 2015). The increment in leaf chlorophyll 
content as a result of treatments might be due to soil application of compost and biofertilizers led to increasing soil organic matter, improves soil structure and increases the water-holding capacity, which reflected to improve availability of macro and micronutrients especially $\mathrm{N}, \mathrm{Mg}$ and $\mathrm{Fe}$. This explanation agree with our data in Tables (3 and 4) and Wassel et al., (2015) who concluded that soil application of farmyard manure, compost and chicken manure improved leaf chlorophyll a, b and its total content on Fig trees.

Table (3). Effect of replacing mineral nitrogen by organic nitrogen and biofertilizers on leaf chlorophyll content of Costata persimmon trees.

\begin{tabular}{|l|c|c|c|c|c|c|}
\hline \multirow{3}{*}{ Treatments } & \multicolumn{6}{|c|}{ Leaf chlorophyll content as $\mathbf{\mu g} / \mathbf{c m}^{\mathbf{2}}$} \\
\cline { 2 - 7 } & \multicolumn{2}{|c|}{$\mathbf{a}$} & \multicolumn{2}{c|}{ b } & \multicolumn{2}{c|}{ Total } \\
\cline { 2 - 7 } & $\mathbf{2 0 1 6}$ & $\mathbf{2 0 1 7}$ & $\mathbf{2 0 1 6}$ & $\mathbf{2 0 1 7}$ & $\mathbf{2 0 1 6}$ & $\mathbf{2 0 1 7}$ \\
\hline $\mathbf{T}_{\mathbf{1}}$ & 62.46 & 63.14 & 28.14 & 28.55 & 90.60 & 91.69 \\
$\mathbf{T}_{\mathbf{2}}$ & 63.65 & 64.53 & 28.79 & 28.80 & 92.44 & 93.33 \\
$\mathbf{T}_{\mathbf{3}}$ & 65.71 & 67.15 & 29.76 & 30.18 & 95.47 & 97.33 \\
$\mathbf{T}_{\mathbf{4}}$ & 64.46 & 65.43 & 29.33 & 29.66 & 93.79 & 95.09 \\
$\mathbf{T}_{\mathbf{5}}$ & 66.80 & 68.21 & 30.17 & 31.35 & 96.97 & 99.56 \\
\hline LSD at 5\% & $\mathbf{1 . 8 5}$ & $\mathbf{2 . 1 1}$ & $\mathbf{0 . 7 8}$ & $\mathbf{0 . 1 1}$ & $\mathbf{2 . 2 5}$ & $\mathbf{2 . 1 6}$ \\
\hline
\end{tabular}

$\mathrm{T}_{1}: 100 \%$ Mineral nitrogen; $\mathrm{T}_{2}: 75 \%$ Mineral nitrogen $+25 \%$ Organic nitrogen; $\mathrm{T}_{3}: 50 \%$ Mineral nitrogen $+25 \%$ Organic nitrogen + Biofertilizer; $\mathrm{T}_{4}: 25 \%$ Mineral nitrogen $+50 \%$ Organic nitrogen + Biofertilizer and $\mathrm{T}_{5}: 100 \%$ Organic nitrogen.

\section{Leaf mineral content:}

Generally, it is obvious from results in Tables (4 and 5) that, application of mineral, organic and biofertilizers enhanced leaf mineral content of Costata persimmon trees. It is also clear that leaf mineral content in the second season proved better compared to first season. Moreover, the results in Tables (4 and 5) revealed that most mineral in leaves is located in adequate range for Costata persimmon growth and productivity under all treatments, these results came true with Wahba, (2002) and George et al., (2005). Anyhow, data in Tables (4 and 5) showed that, Costata persimmon trees fertilized with $\mathrm{T}_{1}\left(100 \%\right.$ mineral nitrogen), $\mathrm{T}_{3}$ (50\% mineral nitrogen $+25 \%$ organic nitrogen + biofertilizer $)$ and $\mathrm{T}_{4}(25 \%$ mineral nitrogen $+50 \%$ organic nitrogen + biofertilizer) had higher $\mathrm{N}, \mathrm{P}, \mathrm{K}, \mathrm{Ca}$ and $\mathrm{Mg}$ than other treatments. Also, treatment of $\mathrm{T}_{5}(100 \%$ organic nitrogen) gave lowest values of leaf $\mathrm{N}, \mathrm{P}, \mathrm{K}, \mathrm{Ca}$ and $\mathrm{Mg}$ contents in both seasons. The results show significant differences among treatments in both seasons as for $\mathrm{N}$ and $\mathrm{Ca}$, while the differences were not significant as for $\mathrm{P}, \mathrm{K}$ and $\mathrm{Mg}$ in both seasons. Moreover, treatments included organic fertilization especially $\mathrm{T}_{5}$, 
$\mathrm{T}_{3}$ and $\mathrm{T}_{4}$ raised leaf $\mathrm{Fe}, \mathrm{Mn}$ and $\mathrm{Zn}$ content compared to other treatments and $100 \%$ mineral nitrogen only. These results were similar to those obtained by Abd El Migeed et al., (2007) and Mansour and Shaaban (2007) who noted that leaf analysis of Washington navel orange trees showed a high level of N, P and $\mathrm{K}$ when treated with nitrogen through mineral at $50 \%$ plus $25 \%$ compost plus biofertilizers. El-Khawaga, (2012) concluded that, soil application of compost enriched with actinomyces at 25 to $50 \%$ and Bacillus polymyxa as a source of nitrogen on mango trees led to improve uptake of $\mathrm{N}, \mathrm{P}$ and $\mathrm{K}$ comparing with using mineral nitrogen only. As regard to micronutrients showed in Table (5) that the uptake of Fe, Mn and $\mathrm{Zn}$ were improved with the application of organic and bio fertilizers. These results were similar with those reported by Mikhael and Aziz (2016a) who revealed that Anna apple trees fertilized with a combination between organic and mineral nitrogen sources had significantly effective in enhancing leaf $\mathrm{Fe}, \mathrm{Mn}$ and $\mathrm{Zn}$ contents compared to the application of nitrogen in the mineral source only.

Table (4). Effect of replacing mineral nitrogen by organic nitrogen and biofertilizers on leaf macronutrients of Costata persimmon trees.

\begin{tabular}{|l|c|c|c|c|c|c|c|c|c|c|}
\hline \multirow{2}{*}{ Treatments } & \multicolumn{2}{|c|}{ N \% } & \multicolumn{2}{c|}{ P \% } & \multicolumn{2}{c|}{ K \% } & \multicolumn{2}{c|}{ Ca \% } & \multicolumn{2}{c|}{ Mg \% } \\
\cline { 2 - 11 } & $\mathbf{2 0 1 6}$ & $\mathbf{2 0 1 7}$ & $\mathbf{2 0 1 6}$ & $\mathbf{2 0 1 7}$ & $\mathbf{2 0 1 6}$ & $\mathbf{2 0 1 7}$ & $\mathbf{2 0 1 6}$ & $\mathbf{2 0 1 7}$ & $\mathbf{2 0 1 6}$ & $\mathbf{2 0 1 7}$ \\
\hline $\mathbf{T}_{\mathbf{1}}$ & 2.31 & 2.43 & 0.172 & 0.178 & 2.36 & 2.34 & 2.16 & 2.22 & 0.64 & 0.64 \\
$\mathbf{T}_{\mathbf{2}}$ & 1.95 & 2.21 & 0.163 & 0.181 & 2.33 & 2.33 & 2.01 & 2.12 & 0.63 & 0.63 \\
$\mathbf{T}_{\mathbf{3}}$ & 2.12 & 2.43 & 0.172 & 0.186 & 2.36 & 2.44 & 2.28 & 2.31 & 0.65 & 0.64 \\
$\mathbf{T}_{\mathbf{4}}$ & 2.12 & 2.33 & 0.174 & 0.174 & 2.34 & 2.36 & 2.10 & 2.13 & 0.64 & 0.63 \\
$\mathbf{T}_{\mathbf{5}}$ & 1.88 & 2.19 & 0.156 & 0.172 & 2.27 & 2.32 & 1.98 & 1.90 & 0.63 & 0.62 \\
\hline LSD at 5\% & $\mathbf{0 . 1 0}$ & $\mathbf{0 . 1 3}$ & $\mathbf{n s}$ & $\mathbf{n s}$ & $\mathbf{n s}$ & $\mathbf{n s}$ & $\mathbf{0 . 1 1}$ & $\mathbf{0 . 1 6}$ & $\mathbf{n s}$ & $\mathbf{n s}$ \\
\hline
\end{tabular}

Table (5). Effect of replacing mineral nitrogen by organic nitrogen and biofertilizers on leaf micronutrients of Costata persimmon trees.

\begin{tabular}{|l|c|c|c|c|c|c|}
\hline \multirow{2}{*}{ Treatments } & \multicolumn{2}{|c|}{ Fe ppm } & \multicolumn{2}{c|}{ Mn ppm } & \multicolumn{2}{c|}{ Zn ppm } \\
\cline { 2 - 7 } & $\mathbf{2 0 1 7}$ & $\mathbf{2 0 1 6}$ & $\mathbf{2 0 1 6}$ & $\mathbf{2 0 1 7}$ & $\mathbf{2 0 1 6}$ & $\mathbf{2 0 1 7}$ \\
\hline $\mathbf{T}_{\mathbf{1}}$ & 75.4 & 77.2 & 46.3 & 45.4 & 17.8 & 18.7 \\
$\mathbf{T}_{\mathbf{2}}$ & 75.9 & 81.8 & 54.7 & 58.3 & 18.8 & 19.7 \\
$\mathbf{T}_{\mathbf{3}}$ & 85.2 & 97.8 & 58.7 & 69.8 & 20.1 & 22.1 \\
$\mathbf{T}_{\mathbf{4}}$ & 79.3 & 88.6 & 56.6 & 60.4 & 19.9 & 20.2 \\
$\mathbf{T}_{\mathbf{5}}$ & 87.6 & 90.6 & 72.1 & 75.2 & 20.1 & 21.1 \\
\hline LSD at 5\% & $\mathbf{4 . 4 5}$ & $\mathbf{3 . 9 5}$ & $\mathbf{1 . 5 4}$ & $\mathbf{4 . 8 6}$ & $\mathbf{0 . 8 0}$ & $\mathbf{1 . 5 3}$ \\
\hline
\end{tabular}

$\mathrm{T}_{1}: 100 \%$ Mineral nitrogen; $\mathrm{T}_{2}: 75 \%$ Mineral nitrogen $+25 \%$ Organic nitrogen; $\mathrm{T}_{3}: 50 \%$ Mineral nitrogen $+25 \%$ Organic nitrogen + Biofertilizer; $\mathrm{T}_{4}: 25 \%$ Mineral nitrogen $+50 \%$ Organic nitrogen + Biofertilizer and $\mathrm{T}_{5}: 100 \%$ Organic nitrogen. 
Generally, it is obvious from Tables (2, 3, 4 and 5) that, vegetative growth and nutritional status of Costata persimmon trees were significantly enhanced by rice straw compost and biofertilizers as a source of nitrogen under calcareous soil. This result can be attributed to influencing soil fertility as: raise the soil microbial population including beneficial microorganisms, better soil structure, enhance the cation exchange capacity and decreased soil $\mathrm{pH}$. This beneficial reflected to enhancing the availability of macro and micronutrients. Therefore, it can be concluded from Tables ( 2 , 3,4 and 5) that, soil application of 50\% mineral nitrogen plus $25 \%$ rice straw compost with biofertilizers improving vegetative growth and nutritional status of Costata persimmon trees compared to mineral nitrogen fertilizers only without significant differences on most cases.

\section{Final fruit set and final fruit drop percentages:}

It appeared from Figure (1) that, final fruit set and final fruit drop percentages were significantly improved by the different fertilization treatments in both seasons. As for final fruit set percentage its clear that, $\mathrm{T}_{3}$ (50\% mineral nitrogen $+25 \%$ organic nitrogen + biofertilizer) exhibited the high final fruit set followed by $\mathrm{T}_{2}(75 \%$ mineral nitrogen $+25 \%$ organic nitrogen) and $\mathrm{T}_{4}(25 \%$ mineral nitrogen $+50 \%$ organic nitrogen + biofertilizer) in both seasons. The differences were not significant among them in both seasons. On the other hand, $\mathrm{T}_{5}(100 \%$ organic nitrogen) gave the lowest values of final fruit set percentage in both seasons. These results are in harmony with those obtained by Ahmed et al., (2013) and Ennab, (2016) on Balady mandarin and Eureka lemon. In this respect, Mikhael and Aziz (2016b) revealed that mixed 50\% organic and 50\% inorganic nitrogen fertilizers had positive effect on fruit set $\%$ of apple trees as compared with mineral nitrogen fertilizers only. Also, the data illustrated in Fig. (1) that, the lowest percentage of final fruit drop were found on trees fertilized by $\mathrm{T}_{3}$, $\mathrm{T}_{2}$ and $\mathrm{T}_{4}$ respectively in both seasons. On contrary, the highest fruit drop percentage was observed on treatment $T_{1}$ and $T_{5}$ respectively. Similar results were obtained by El Saady and El-Abd, (2012) and Ahmed et al., (2013) they reported organic, biofertilizers and NPK alone or combined together significantly decreased the percentages of June drop and preharvest drop in navel orange. So, it can be concluded that, final fruit set and final fruit drop of Costata persimmon trees were positively affected by organic and biofertilizers with doses of mineral nitrogen fertilizers in both seasons. In this respect, organic and bio-fertilizers gave the best fruit set and also reduced final fruit drop especially $\mathrm{T}_{4}$ and $\mathrm{T}_{3}$ compared to other treatments. 

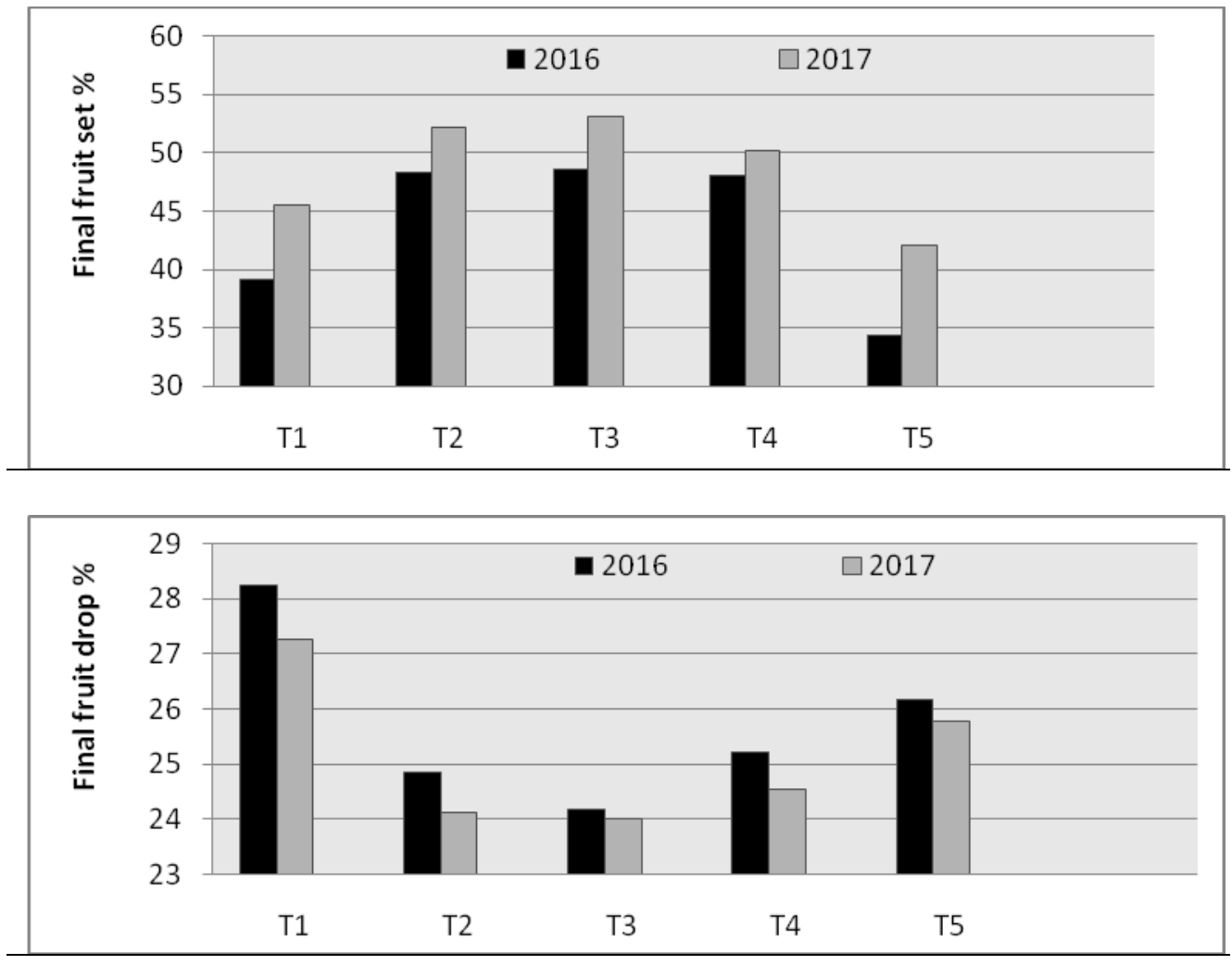

Figure (1). Effect of replacing mineral nitrogen by organic nitrogen and biofertilizers on fruit set $\%$ and fruit drop $\%$ of Costata persimmon trees.

$\mathrm{T}_{1}: 100 \%$ mineral nitrogen; $\mathrm{T}_{2}: 75 \%$ mineral nitrogen $+25 \%$ organic nitrogen; $\mathrm{T}_{3}$ : $50 \%$ mineral nitrogen $+25 \%$ organic nitrogen + biofertilizer; $\mathrm{T}_{4}: 25 \%$ mineral nitrogen $+50 \%$ organic nitrogen + biofertilizer and $\mathrm{T}_{5}: 100 \%$ organic nitrogen.

\section{Yield:}

Results in Table (6) showed that, rice straw compost and biofertilizers treatments with nitrogen dose were significantly increased fruit yield of Costata persimmon expressed as number of fruits/tree, $\mathrm{kg} /$ tree and total yield as ton/feddan in both seasons. Treatments of $\mathrm{T}_{3}(50 \%$ mineral nitrogen $+25 \%$ organic nitrogen + biofertilizer $)$ and $\mathrm{T}_{2}(75 \%$ mineral nitrogen $+25 \%$ organic nitrogen) tended to gave the highest values of yield as number of fruits/tree, $\mathrm{kg} /$ tree and ton/feddan without significant differences between them in both seasons. On contrary, using $100 \%$ rice straw compost as a source of nitrogen only produced the lowest values of yield in both seasons. In this respect, $\mathrm{T}_{4}(25 \%$ mineral nitrogen $+50 \%$ organic nitrogen + 
biofertilizer) and $\mathrm{T}_{1}(100 \%$ mineral nitrogen) produced moderate yield in both seasons. These results are in agreement with those obtained by Mansour and Shaaban (2007). In this respect, Dheware and Waghmare, (2009) on sweet orange, they reported that, number of fruits per tree and average weight of fruits significantly increased with organic, inorganic fertilizers and inoculation by Azospirillum. Also, Mikhael and Aziz (2016b) revealed that Anna apple tree fertilized with 50\% mineral nitrogen plus 50\% organic manure bearing higher yield (kg/tree) than that fertilized with $100 \%$ mineral nitrogen only. The beneficial effect of organic and biofertilizers on improving yield of Costata persimmon maybe due to positive effect on nutrients uptake (Tables 4 and 5) which reflected on active vegetative growth parameters in Table (2). Also the positive response of yield as a result of biofertilizers treatments maybe due to the high ability of these microbes in nitrogen fixation and the secretion of several compounds that increase soil fertility, and organic matter increase bacteria activity, number of this bacteria, thus it can fix atmospheric nitrogen, increase phosphorus availability in soil and enhanced absorb elements by Costata persimmon tree, that reflected to tree's ability to grow and increase productivity. Also, yield was increase as a result of increasing fruit set and decreasing fruit drop percentages. These conclusions agree with the result obtained by Wassel et al., (2015) and our data in Fig. (1).

Table (6). Effect of replacing mineral nitrogen by organic nitrogen and biofertilizers on yield of Costata persimmon trees.

\begin{tabular}{|l|c|c|c|c|c|c|}
\hline \multirow{2}{*}{ Treatments } & \multicolumn{2}{|c|}{ Fruit number/tree } & \multicolumn{2}{c|}{ Kg/tree } & \multicolumn{2}{c|}{ Ton/feddan } \\
\cline { 2 - 7 } & $\mathbf{2 0 1 6}$ & $\mathbf{2 0 1 7}$ & $\mathbf{2 0 1 6}$ & $\mathbf{2 0 1 7}$ & $\mathbf{2 0 1 6}$ & $\mathbf{2 0 1 7}$ \\
\hline $\mathbf{T}_{\mathbf{1}}$ & 239.8 & 243.8 & 29.55 & 31.17 & 7.68 & 8.10 \\
$\mathbf{T}_{\mathbf{2}}$ & 265.6 & 258.2 & 34.90 & 35.53 & 9.07 & 9.23 \\
$\mathbf{T}_{\mathbf{3}}$ & 253.6 & 249.3 & 35.33 & 35.98 & 9.18 & 9.35 \\
$\mathbf{T}_{\mathbf{4}}$ & 238.7 & 259.3 & 30.70 & 33.83 & 7.98 & 8.79 \\
$\mathbf{T}_{\mathbf{5}}$ & 232.8 & 239.2 & 28.22 & 29.17 & 7.33 & 7.58 \\
\hline LSD at 5\% & $\mathbf{1 . 5 1}$ & $\mathbf{8 . 8 8}$ & $\mathbf{2 . 2 3}$ & $\mathbf{0 . 8 7}$ & $\mathbf{0 . 2 3}$ & $\mathbf{0 . 3 4}$ \\
\hline
\end{tabular}

$\mathrm{T}_{1}: 100 \%$ Mineral nitrogen; $\mathrm{T}_{2}: 75 \%$ Mineral nitrogen $+25 \%$ Organic nitrogen; $\mathrm{T}_{3}: 50 \%$ Mineral nitrogen $+25 \%$ Organic nitrogen + Biofertilizer; $\mathrm{T}_{4}: 25 \%$ Mineral nitrogen $+50 \%$ Organic nitrogen + Biofertilizer and $\mathrm{T}_{5}: 100 \%$ Organic nitrogen.

\section{Fruit quality:}

\section{Physical characters:}

Data in Table (7) show the effect of application of mineral, organic nitrogen and biofertilizers on physical fruit quality in terms of fruit weight, length, and diameter and fruit firmness of Costata persimmon trees in both 
Table (7). Effect of replacing mineral nitrogen by organic nitrogen and biofertilizers on physical fruit quality of Costata persimmon trees.

\begin{tabular}{|l|c|c|c|c|c|c|c|c|}
\hline \multirow{2}{*}{ Treatments } & \multicolumn{2}{|c|}{$\begin{array}{c}\text { Fruit weight } \\
(\mathbf{g})\end{array}$} & \multicolumn{2}{c|}{$\begin{array}{c}\text { Fruit length } \\
(\mathbf{c m})\end{array}$} & \multicolumn{2}{c|}{$\begin{array}{c}\text { Fruit } \\
\text { diameter } \\
(\mathbf{c m})\end{array}$} & \multicolumn{2}{c|}{$\begin{array}{c}\text { Fruit firmness } \\
\text { (lb/inch }\end{array}$} \\
\cline { 2 - 9 } & $\mathbf{2 0 1 6}$ & $\mathbf{2 0 1 7}$ & $\mathbf{2 0 1 6}$ & $\mathbf{2 0 1 7}$ & $\mathbf{2 0 1 6}$ & $\mathbf{2 0 1 7}$ & $\mathbf{2 0 1 6}$ & $\mathbf{2 0 1 7}$ \\
\hline $\mathbf{T}_{\mathbf{1}}$ & 123.19 & 127.82 & 6.22 & 6.33 & 6.45 & 6.56 & 20.79 & 19.76 \\
$\mathbf{T}_{\mathbf{2}}$ & 131.40 & 137.56 & 5.71 & 5.93 & 5.94 & 6.16 & 17.53 & 16.79 \\
$\mathbf{T}_{\mathbf{3}}$ & 139.27 & 144.30 & 7.03 & 7.18 & 7.24 & 7.39 & 19.06 & 18.41 \\
$\mathbf{T}_{\mathbf{4}}$ & 128.60 & 130.42 & 5.63 & 5.87 & 5.86 & 6.11 & 18.79 & 18.22 \\
$\mathbf{T}_{\mathbf{5}}$ & 121.21 & 121.94 & 5.25 & 5.43 & 5.49 & 5.68 & 23.44 & 22.60 \\
\hline LSD at 5\% & $\mathbf{1 . 5 0}$ & $\mathbf{1 . 8 4}$ & $\mathbf{0 . 1 5}$ & $\mathbf{0 . 0 8}$ & $\mathbf{0 . 4 2}$ & $\mathbf{0 . 2 3}$ & $\mathbf{0 . 8 4}$ & $\mathbf{0 . 7 2}$ \\
\hline
\end{tabular}

$\mathrm{T}_{1}: 100 \%$ Mineral nitrogen; $\mathrm{T}_{2}: 75 \%$ Mineral nitrogen $+25 \%$ Organic nitrogen; $\mathrm{T}_{3}: 50 \%$ Mineral nitrogen $+25 \%$ Organic nitrogen + Biofertilizer; $\mathrm{T}_{4}: 25 \%$ Mineral nitrogen $+50 \%$ Organic nitrogen + Biofertilizer and $\mathrm{T}_{5}: 100 \%$ Organic nitrogen.

seasons. As for fruit weight, trees fertilized by $\mathrm{T}_{3}(50 \%$ mineral nitrogen + $25 \%$ organic nitrogen + biofertilizer) had the heaviest fruit weight followed by those fertilized by $\mathrm{T}_{2}, \mathrm{~T}_{4}, \mathrm{~T}_{1}$ and $\mathrm{T}_{5}$ in both seasons, respectively. The differences were significant among treatments in both seasons. Similar results were obtained by Mansour et al., (2013) and El Sehrawy, (2015). With regard the effect of treatments on fruit length and diameter, $\mathrm{T}_{3}(50 \%$ mineral nitrogen $+25 \%$ organic nitrogen + biofertilizer) gave the highest values of fruit length and diameter followed by $\mathrm{T}_{1}(100 \%$ mineral nitrogen) with significant differences between them in both seasons. $\mathrm{T}_{2}(75 \%$ mineral nitrogen $+25 \%$ organic nitrogen) and $\mathrm{T}_{4}(25 \%$ mineral nitrogen $+50 \%$ organic nitrogen + biofertilizer) gave intermediate values in this respect. Whereas, $T_{5}(100 \%$ organic nitrogen) gave the least values of fruit length and diameter in both seasons. These results agree with those obtained by Mikhael and Aziz (2016b). Also, it's clear from Table (7) that, Costata persimmon fertilized by $\mathrm{T}_{5}(100 \%$ organic nitrogen) had the highest fruit firmness followed by $\mathrm{T}_{1}(100 \%$ mineral nitrogen) in both seasons. On the other hand, $\mathrm{T}_{2}(75 \%$ mineral nitrogen $+25 \%$ organic nitrogen) gave the lowest values of fruit firmness in both seasons. These results agree with those obtained by Salama et al., (2012).

Generally, it is clear from Table (7) that, heaviest and largest fruits with a good fruit firmness were harvest from trees treated $\mathrm{T}_{3}(50 \%$ mineral nitrogen $+25 \%$ organic nitrogen + biofertilizer $), \mathrm{T}_{2}(75 \%$ mineral nitrogen $+25 \%$ organic nitrogen $)$ and $\mathrm{T}_{4}(25 \%$ mineral nitrogen $+50 \%$ organic nitrogen + biofertilizer) in both seasons. 


\section{Chemical characters:}

Results in Table (8) show the effect of soil application of mineral and organic nitrogen as well as biofertilizers on chemical fruit quality in terms of TSS $\%$, acidity $\%$ and total tannins $\%$ of Costata persimmon trees in both seasons. Fertilization of Costata persimmon trees with $\mathrm{T}_{5}(100 \%$ organic nitrogen) produced fruits had the highest TSS\% and lowest acidity and total tannins followed by $\mathrm{T}_{3}(50 \%$ mineral nitrogen $+25 \%$ organic nitrogen + biofertilizer) and $\mathrm{T}_{4}(25 \%$ mineral nitrogen $+50 \%$ organic nitrogen + biofertilizer) in both seasons. Whereas, $\mathrm{T}_{1}$ (100\% mineral nitrogen) gave the lowest values of TSS and the highest values of acidity and total tannins in both seasons. These results agree with those obtained by Salama et al., (2012), Mansour et al., (2013), El Sehrawy, (2015) and Mikhael and Aziz (2016b).

Table (8). Effect of replacing mineral nitrogen by organic nitrogen and biofertilizers on some chemical fruit quality of Costata persimmon trees.

\begin{tabular}{|l|c|c|c|c|c|c|}
\hline \multirow{2}{*}{ Treatments } & \multicolumn{2}{|c|}{$\begin{array}{c}\text { TSS } \\
\text { \% }\end{array}$} & \multicolumn{2}{c|}{$\begin{array}{c}\text { Acidity } \\
\text { \% }\end{array}$} & \multicolumn{2}{c|}{$\begin{array}{c}\text { Total tannins mg/100 } \\
\text { ml juice }\end{array}$} \\
\cline { 2 - 7 } & $\mathbf{2 0 1 6}$ & $\mathbf{2 0 1 7}$ & $\mathbf{2 0 1 6}$ & $\mathbf{2 0 1 7}$ & $\mathbf{2 0 1 6}$ & $\mathbf{2 0 1 7}$ \\
\hline $\mathbf{T}_{\mathbf{1}}$ & 19.72 & 20.69 & 0.39 & 0.39 & 2.46 & 2.55 \\
$\mathbf{T}_{\mathbf{2}}$ & 20.78 & 22.10 & 0.35 & 0.35 & 2.10 & 2.21 \\
$\mathbf{T}_{\mathbf{3}}$ & 22.46 & 23.26 & 0.32 & 0.33 & 1.96 & 2.06 \\
$\mathbf{T}_{\mathbf{4}}$ & 21.78 & 21.94 & 0.32 & 0.32 & 2.07 & 2.19 \\
$\mathbf{T}_{\mathbf{5}}$ & 24.73 & 25.73 & 0.29 & 0.30 & 2.22 & 2.32 \\
\hline LSD at & $\mathbf{0 . 3 1}$ & $\mathbf{0 . 7 3}$ & $\mathbf{0 . 0 1}$ & $\mathbf{0 . 0 5}$ & $\mathbf{0 . 1 5}$ & $\mathbf{0 . 1 0}$ \\
$\mathbf{5 \%}$ & & & & & & \\
\hline
\end{tabular}

$\mathrm{T}_{1}: 100 \%$ Mineral nitrogen; $\mathrm{T}_{2}: 75 \%$ Mineral nitrogen $+25 \%$ Organic nitrogen; $\mathrm{T}_{3}: 50 \%$ Mineral nitrogen $+25 \%$ Organic nitrogen + Biofertilizer; $\mathrm{T}_{4}: 25 \%$ Mineral nitrogen $+50 \%$ Organic nitrogen + Biofertilizer and $\mathrm{T}_{5}: 100 \%$ Organic nitrogen.

\section{Nitrate and nitrite contents:}

Fertilizers types and its amounts used especially mineral nitrogen fertilizers influence on the concentration of nitrate and nitrite in fruit juice. In order to improve productivity and access to safe fruits for local consumer and high exportation potential, tree nutrition should be depending on minimizing amounts of chemical fertilizers especially mineral nitrogen fertilizer through satisfying the nitrogen requirement from organic nitrogen and biofertilization. So, our results in Figure (2) revealed that, fruit juice nitrate and nitrite contents were significantly decreased by different treatments in the two seasons comparing with $100 \%$ mineral nitrogen, which gave the highest values on nitrate and nitrite contents $(2.80$ and $2.74 \mathrm{mg} / 100$ 

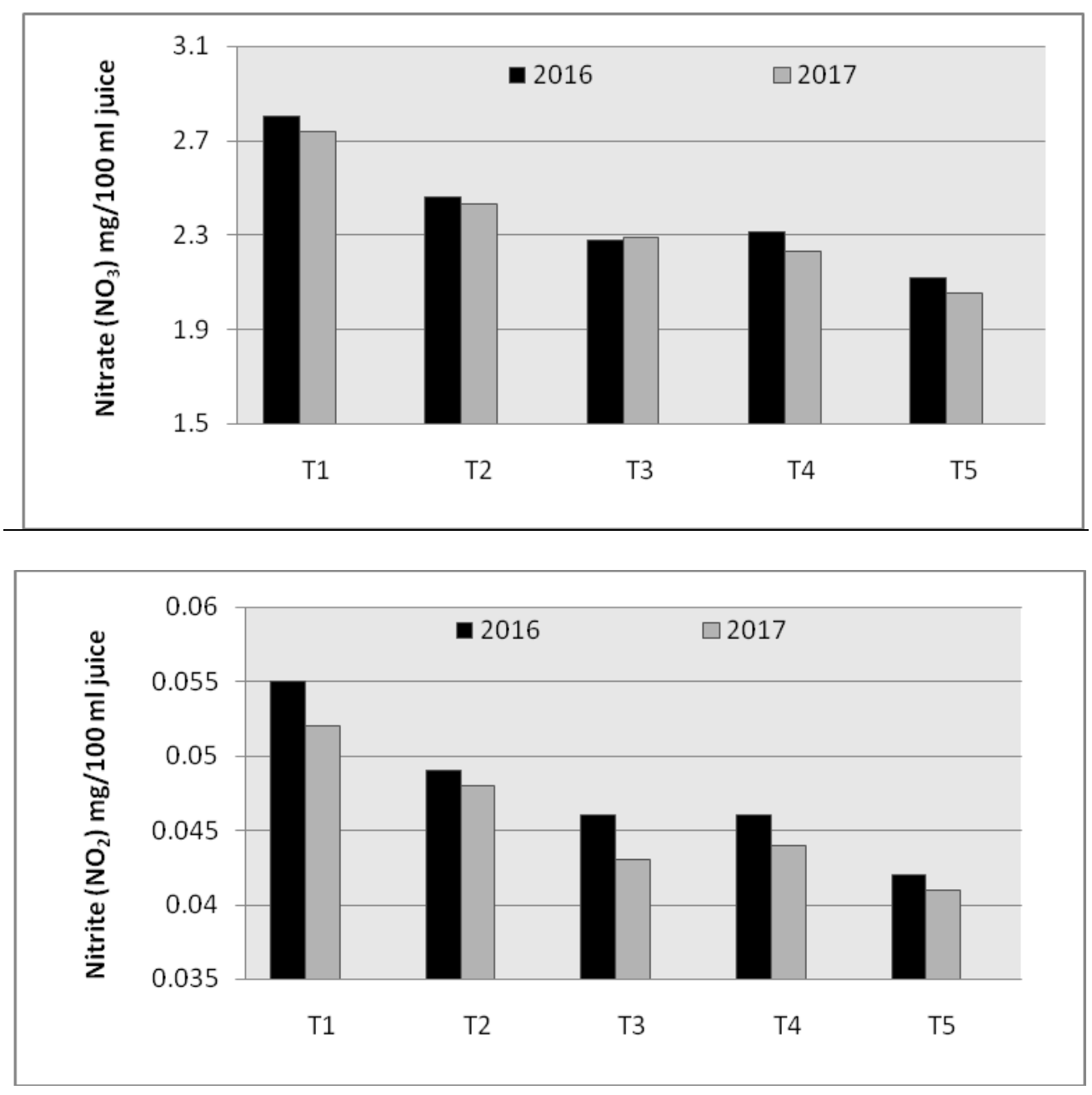

Figure (2). Effect of replacing mineral nitrogen by organic nitrogen and biofertilizers on nitrate and nitrite in fruit juice $\mathrm{mg} / 100$ juice of Costata persimmon trees. $\mathrm{T}_{1}: 100 \%$ Mineral nitrogen; $\mathrm{T}_{2}: 75 \%$ Mineral nitrogen $+25 \%$ Organic nitrogen; $\mathrm{T}_{3}: 50 \%$ Mineral nitrogen $+25 \%$ Organic nitrogen + Biofertilizer; $\mathrm{T}_{4}: 25 \%$ Mineral nitrogen $+50 \%$ Organic nitrogen + Biofertilizer and $\mathrm{T}_{5}: 100 \%$ Organic nitrogen.

$\mathrm{ml}$ juice), $(0.055$ and $0.052 \mathrm{mg} / 100 \mathrm{ml}$ juice) followed by $75 \%$ mineral nitrogen $+25 \%$ organic nitrogen $(2.46$ and $2.43 \mathrm{mg} / 100 \mathrm{ml}$ juice $),(0.049$ and $0.048 \mathrm{mg} / 100 \mathrm{ml}$ juice). Meanwhile, trees fertilized by $100 \%$ organic and $50 \%$ mineral nitrogen $+25 \%$ organic nitrogen + biofertilizers produced 
fruits with low nitrate and nitrite contents in both seasons. These results agree with those obtained by Abd El Wahab, (2011), Ahmed et al., (2015), El Sehrawy, (2015) and Mikhael and Aziz (2016b). They concluded that, trees fertilizing by organic, biofertilizers with $50 \%$ doses of mineral nitrogen led to reduced nitrate and nitrite values in fruit juice comparing with $100 \%$ mineral nitrogen fertilizer. This conclusion agree with our results in Fig. (2) which cleared that values of replacing nitrogen fertilization partially through using only $50 \%$ mineral nitrogen $+25 \%$ organic nitrogen + biofertilizer instead of $100 \%$ mineral nitrogen had a beneficial effect on reducing nitrate and nitrite in fruit juice.

Generally, it is obvious from Tables (7 and 8) and Fig. (2) that, fertilization with organic nitrogen and biofertilizers, with doses of mineral nitrogen are able to consistently improve fruit quality in terms of fruit weight, length, diameter, firmness, TSS, acidity, total tannins, nitrate and nitrite of Costata persimmon trees compared to mineral nitrogen only. In this respect, $50 \%$ mineral nitrogen $+25 \%$ organic nitrogen + biofertilizers produced best fruit quality compared to other treatments. These results agree with those obtained by Abd El Migeed et al., (2007) and Abd El Wahab (2011).

Conclusively, consequently from the previously mentioned results, it was clear the main role of organic nitrogen and biofertilizers with different doses of mineral nitrogen on Costata persimmon trees grown in calcareous soil, for supply nitrogen which indispensable for improvement of growth and the nutritional status of the Costata persimmon trees and production of maximum yield with a good quality. Also, organic nitrogen and biofertilizers could compensate $50 \%$ of mineral nitrogen without significant reduction in yield. Therefore, this treatment is recommended $(50 \%$ mineral nitrogen + $25 \%$ organic nitrogen + biofertilizers). This treatment gave the best growth, yield, fruit quality and nutritional status of Costata persimmon trees.

\section{REFERENCES}

Abd El Migeed, M.M.; M.M. Saleh and E.A. Mostafa (2007). The beneficial effect of minimizing mineral nitrogen fertilization on Washington navel orange trees by using organic and biofertilizers. World J. Agric. Sci., 3(1):80 - 85.

Abd El Wahab, M.A. (2011). Reducing the amount of mineral nitrogen fertilizers for Red Globe grapevines by using different sources of organic fertilizers. Journal of American Science, 7(8):810 - 819. 
Abou Grah, F.I.I. (2004). Studies on fertilization of persimmon trees (Diospyros sp.). Ph D. Thesis Fac. Agric., Moshtohor, Zagazig University, Egypt.

Ahmed, F.F.; A.H. Abdelaal; S.E. El- Masry and S.M. Hassan (2015). Using some organic manures and EM as a partial replacement of mineral $\mathrm{N}$ fertilizers in Superior vineyards. World Rural Observ., 7(3):76-84.

Ahmed, F.F.; A.H. Abdelaal and M.H. Faraag (2013). Partial replacement of inorganic $\mathrm{N}$ fertilizer in Balady mandarin orchards by using organic and biofertilization. Stem 4(2):21 - 28 .

Association of official Agriculture chemists (1990). Official And Tentative Methods Of Analysis, 13th ed. Washington, D. C., USA.

Brown, J.D. and O. Lillelland (1974). Rapid determination of potassium and sodium in plant material and soil extracts by flame photometer. Proc. Soc. Hort. Sci., 48: 341-346.

Chapman, H.D. and P.F. Pratt (1961). Methods of Analysis for Soils, Plant and Waters. Univ. of California, USA, pp. 169-170.

Choi, S.; D. Park; G. Ahn; S. Kim, and T. Choi (2013). Tree growth and nutritional changes in senescing leaves of Fuyu persimmon as affected by different nitrogen rates during summer. Kor. J. Hort. Sci. Technol. , 31(6):706 - 713 .

Dheware, R.M. and M.S. Waghmare (2009). Influence of organic-inorganic and biofertilizers and their interactions on number of fruits per tree and average weight of fruit of sweet orange (Citrus sinensis Osbeck L.). Intern. J. Agric. Sci., 5(1):251 - 253.

El Gioushy, S.F. and M.H.M. Baiea (2015). Partial substitution of chemical fertilization of Canino apricot by bio and organic fertilization. Middle East Journal of Applied Sciences, (5)4:823 - 832.

El Khawaga, A.S. (2012). Effect of compost enriched with actinomyces and Bacillus polymyxa algae as a partial substitute for mineral $\mathrm{N}$ in Ewaise mango orchards. Res. J. Agric. \& Biol. Sci., 8(2):191 - 196.

El Saady, A.S. and A.A. Al-Abd (2012). Effect of balanced fertilizer splitting on navel orange yield and fruit quality. J. Soil Sci. and Agric. Eng., Mansoura Univ., 3(1):41 - 51.

El Salhy, A.M.; H.A. Abd El-Galil, A.H. Abd El-Aal and M.M. Ali (2010). Effect of different nitrogen fertilizer sources on vegetative Growth, nutrient status and fruiting of Balady mandarin trees. Assiut J. of Agric. Sci., 41 (Special Issue ) (The 4th Conference of Young Scientists Fac. of Agric. Assiut Univ. April, 27, pp:153 - 170. 
El Sehrawy, O.A.M. (2015). Reducing the amount of nitrate and nitrite in Anna apple fruits by using inorganic $\mathrm{N}$ along with $\mathrm{EM}$, yeast and humic cid. Alex. Sci., Exch., J., 36(2):188 - 196.

Ennab, H.A. (2016). Effect of organic manures, biofertilizers and NPK on vegetative growth, yield, fruit quality and soil fertility of Eureka lemon trees (Citrus limon (L.) Burm). J. Soil Sci. and Agric. Eng., Mansoura Univ.,7(10):767 - 774.

Gabr, M.A. and M. Nour El-Din (2012). Evaluation of selected Azospirillum spp. isolates for IAA production and fruit potential impact on improving growth, yield and fruit quality of Anna apple trees. J. Agric. Chem. and Biotechn. , Mansoura Univ., 3(3):65 - 75.

George, A.; B. Nissen and R. Broadley (2005). Persimmon nutrition: a practical guide to improving fruit quality and production. Department of Primary Industries, Queensland Horticulture Institute, Queensland.( era.daf.qld.gov.au/2210/8/Chapter_05.pdf).

Jackson, M.L. (1967). Soil Chemical and Analysis. Prentice Hall of India, New Delhi, p. 498.

Mansour, A.E.M. and E.A. Shaaban (2007). Effect of different sources of mineral $\mathrm{N}$ applied with organic and bio fertilizers on fruiting of Washington navel orange trees. Journal of Applied Sciences Research, 3(8):764 - 769 .

Mansour, A.E.M.; F.F. Ahmed; A.M.K. Abdelaal; R.A.R. Eissa and O.A.M. Sehrawy (2013). The beneficial of using some biostimulants as a partial replacement of chemical $\mathrm{N}$ fertilizers in Florida prince peach orchards. J. Appl. Sci. Res., 9(1):867 - 871.

Masoud A.A. (2012). Effect of organic and bio nitrogen fertilization on growth, nutrient status and fruiting of Flame seedless and Ruby seedless grapevines. Res. J. Agric. \& Biol. Sci., 8(2):83 - 91.

Mikhael, G.B.Y. and M.A. Aziz (2016a). Effect of replacing mineral nitrogen by organic manures under different irrigation regimes on: A. Vegetative growth and nutritional status of Anna apple trees. J. Plant Production, Mansoura Univ., 7(2):203 - 216.

Mikhael, G.B.Y. and M.A. Aziz (2016b). Effect of replacing mineral nitrogen by organic manures under different irrigation regimes on: $B$. Productivity and water use efficiency of Anna apple trees. J. Plant Production, Mansoura Univ., 7(2):217 - 230.

Mohammadi, S. and P. Ziarati (2016). Nitrate and nitrite content in commercially-available fruit juice packaged products. J. Chem. Pharm. Res., 8(6):335 - 341. 
Moran, R. and D. Porath (1980). Chlorophyll determination in intact tissues using N, N dimethyl formamide. Plant Physiol., 65:478-479.

Murphy, J. and Riley, J.R. (1962). A modified single solution method for the determination of phosphorus in natural water. Anal. Chem., Acta, 27: 31-38.

Page, A.L.; Miller H. and Keeney, D.R. (1982). Methods Of Soil Analysis. Part 2: Chemical and microbiological properties. 2nd Edition, Agronomy Monograph, No. 9, ASA, CSSA, and SSSA, Madison.

Pregl, F. (1945). Quantitative Organic Microanalysis, 4th ed J.A. Churchill, Ltd, London.

Salama, M.I.; A.F. El-Sammak; A.A. El-Morsy and K.M. Aly (2012). The beneficial effect of minimizing mineral nitrogen fertilization on Sewy date palm trees by using organic and biofertilizers. J. Plant Production, Mansoura Univ., 3 (9):2411 - 2424.

Shah, S.M.; W. Mohammad; S.A. Shah and H. Nawaz (2006). Integrated nitrogen management of young deciduous apricot orchard. Soil and Environ., 25(1):59-63.

Snedecor, G.W. and W.G. Cochran (1990).Statistical methods. 7th Ed. Iowa State Univ. Press. Ames., Iowa, USA, p. 593.

Suhag, M. (2016). Potential of biofertilizers to replace chemical fertilizers. International Advanced Research Journal in Science, Engineering and Technology, 3(5):163 - 167.

Wahba, M.M.M. (2002). Physiological studies on growth and flowering of some persimmon varieties. M.Sc. Thesis, Fac. Agric. Moshtohor, Zagazig University Banha Branch. Egypt.

Wassel, A.M.; A.M.K. Abdelaal; A.M. Goda and M.H. Abdel Aziz (2015). Response of Kadotta fig using some organic manures enriched with EM as a partial substitution of mineral $\mathrm{N}$ fertilizer. Word Rural Observation, 7(2):22 - 29.

Zayan, M.A.; R.A. Sayed; A.R. El-Sherif and H.M. El-Zawily (2016). Irrigation and fertilization programs for Washington navel orange trees in sandy soil under desert climatic conditions. 1. Effect on soil properties, vegetative growth and yield. J. Agric. Res., Kafr El-Sheikh Univ. A. Plant Production, 42(2):210 - 233. 


\title{
الحد من التسميد النيتروجينى با ستخدام الأسمدة العضوية

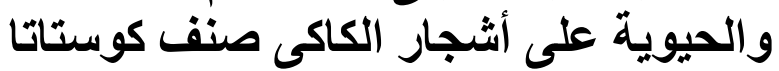

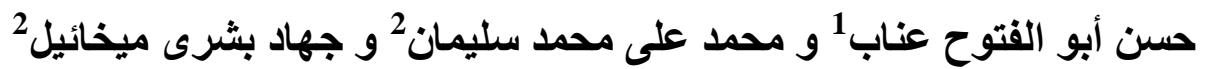

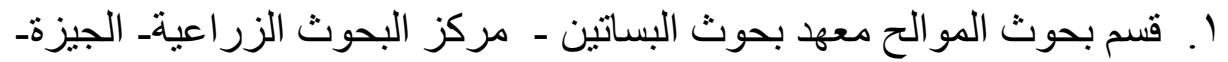 \\ r. قُم بحوث الفاكهة متساقطة الأوراق معهد بحوث البساتين - مركز البحوث

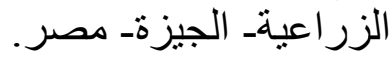

أجريت هذه الدراسة خلال مواسم 2015 و 2016 و 2017 لدار اسة تأثير

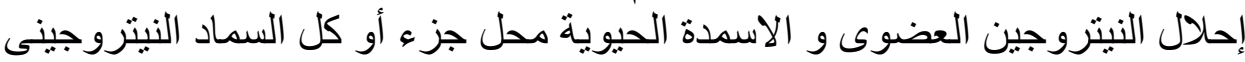

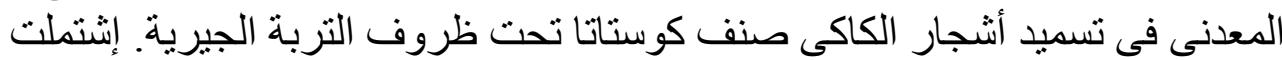

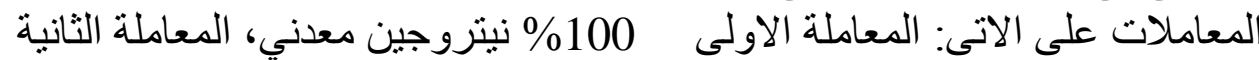

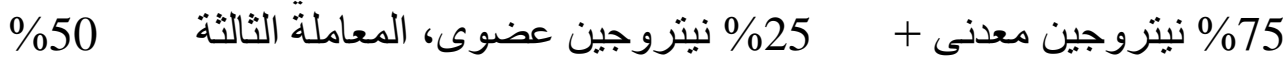

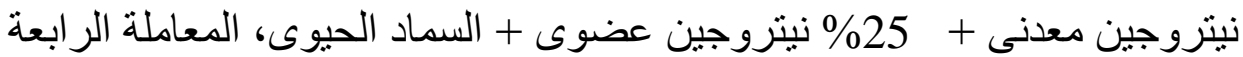

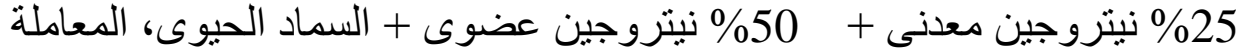

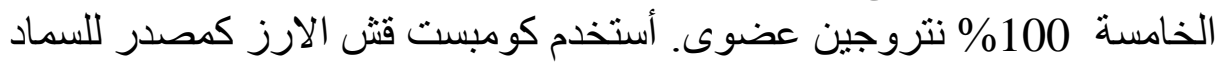
العضوى و خليط من بكتريا حرة تثبت النيتروجين الجوى هي أنئ أزوتوبكتر

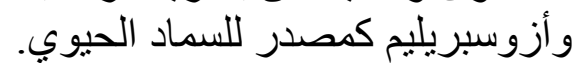
و يمكن تلخيص النتائج التي تم الحصول عليماليها على التئ النحو التالي:

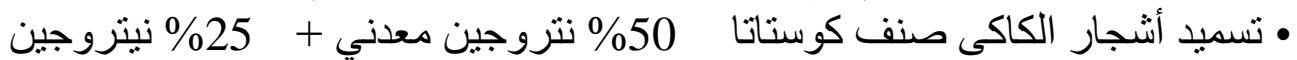

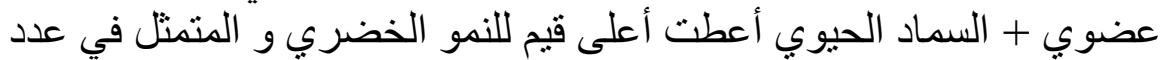

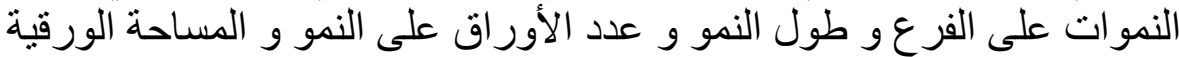

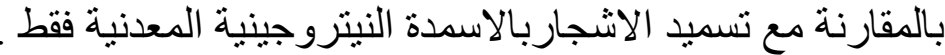

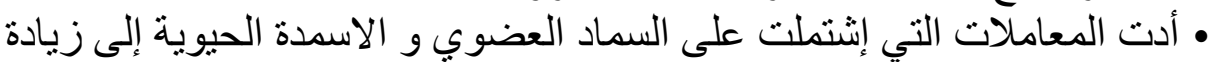

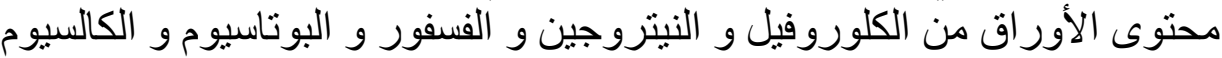

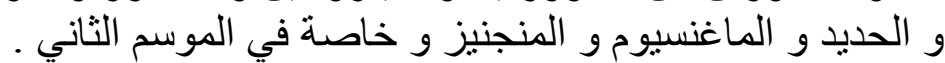

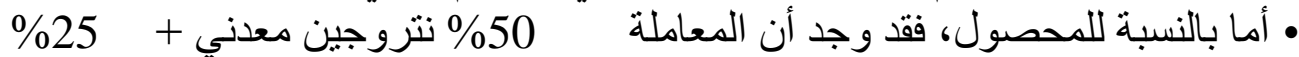

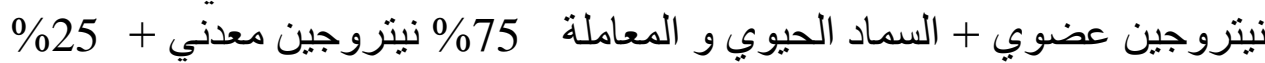

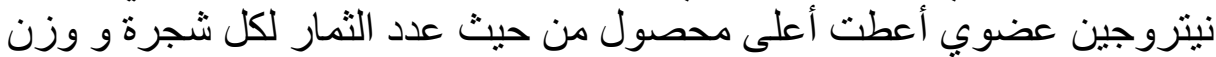
الثمار لكل شجرة و محصول الفدان بالطن. 


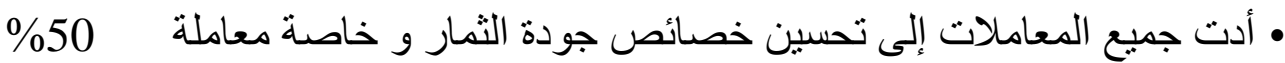
نتروجين معدني + 25\% نيتروجين عضوي المعامئ + السماد الحيوي.

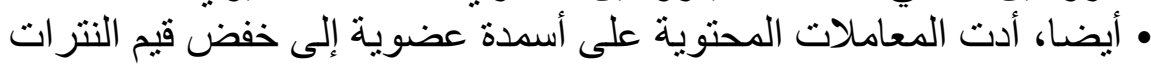
والنيتريت في عصير الثمار.

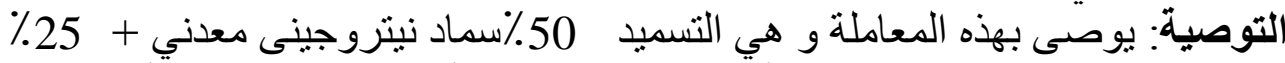

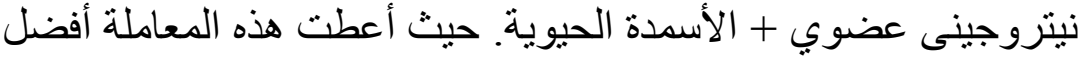

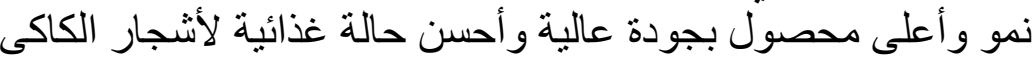

صنف كوستاتا. 